\title{
Redação científica: entre a descoberta e a publicação
}

\author{
JOSÉ TEREZIANO BARROS NETO ${ }^{1}$
}

\begin{abstract}
Scientific writing: from discovery to publication) Some scientific texts, despite their excellent content, may not perform their role of knowledge disseminating, because they lack quality of writing. Discerning readers could relate the carelessness in writing with the possible lack of care with data dealing, and will doubt the accuracy in the application of the method and collecting data. Research groups almost always have a statistician; almost never a portuguese language reviewer. This article contains some insights that may help to better understand the issue of vowel a contraction and punctuation.
\end{abstract}

Keywords - editorial policy, portuguese language, scientific writing quality

RESUMO - (Redação científica: entre a descoberta e a publicação) Alguns textos científicos, apesar de seu excelente conteúdo, podem não cumprir seu papel de disseminação de conhecimentos, por lhes faltar qualidade redacional. Leitores criteriosos poderão relacionar a falta de cuidado na redação com a possível falta de cuidado ao tratar os dados, bem como duvidarão do esmero na aplicação do método e na coleta dos resultados. Grupos de pesquisa geralmente contam com a assessoria de um estatístico, mas não de um revisor de língua portuguesa. Este artigo contém alguns insights que poderão ajudar a melhor entender a questão da crase e da pontuação.

Palavras-chave - língua portuguesa, política editorial, qualidade da redação científica

\section{Introdução}

Em função da natural diversidade de caracteres humanos e respectivas habilidades, as carreiras profissionais são determinadas pela maior afinidade entre o indivíduo e área em perspectiva. Os mais falantes preferirão exercer atividades que melhor ressaltem suas aptidões e, preferentemente, diante de um grande público. Os que apresentam maior facilidade de concentração preferirão um ambiente mais calmo, isolado, mais adequado aos seus anseios de estudo e pesquisa. Há os mais práticos, que se maravilham com a mágica dos números, sempre exatos e aplicáveis em todas as atividades humanas. As descobertas feitas pelos pesquisadores precisam ser divulgadas, ou não fariam sentido as horas e recursos investidos. Para que a comunidade científica possa se beneficiar com as conclusões, os dados obtidos precisam ser adequadamente tratados e a redação final submetida a uma revisão gramatical.

A pesquisa nacional tem obtido conquistas surpreendentes. Esses resultados podem ficar restritos a uma pequena comunidade ou espraiar-se pela comunidade científica internacional. Vários fatores interferem nesse processo de divulgação, como valor das descobertas,

1. Universidade Paranaense - UNIPAR. Especialista em Produção de Texto em Língua Portuguesa. Avenida Pernambuco 3516, 87501-550 Umuarama, PR, Brasil.

2._Autor para correspondência: tereziano@uol.com.br aplicabilidade dos resultados, meio de divulgação escolhido, língua utilizada na divulgação e redação. Intencionalmente colocada como último item, a redação pode pôr a perder todo o trabalho de pesquisa e as verbas gastas, bem como o cuidado na escolha da revista e da língua em que os resultados serão publicados. Mal redigido, o texto pode não conter - ou não deixar claros - elementos essenciais para entendimento e utilização do método por outros cientistas, visando à validação dos resultados obtidos, para outros espécimes, em outras regiões.

Alguns professores de cursinhos preparatórios para concursos e vestibulares têm procurado "facilitar" a fixação de regras gramaticais por meio de esquemas mentais. Além de não explicarem os porquês de determinadas regras, esses mecanismos não abrangem todos os contextos. Este artigo não tem o condão de resolver todos os problemas de pontuação e do uso do acento grave, indicativo de crase, nem era essa a minha pretensão. Se algum leitor mudar o seu (pre)conceito sobre esses dois aspectos, talvez consiga "fazer as pazes" com a gramática.

\section{A crase não é um acento}

A simples menção à crase faz eminentes cientistas sofrerem uma dolorida queda em sua autoestima. "Nunca entendi quando usar esse acento. Nunca sei quando tem e quando não tem crase. Por que tanta celeuma por um risquinho? Fico perdido no meio de tantas regras!" O 
que se perdeu, a bem da verdade, foi o processo ensino/ aprendizagem. Não "existe" crase. Não é algo que o texto "tem" ou deixa de ter. Nem se trata de um acento. $\mathrm{O}$ que se costuma chamar de crase é o acento grave, indicativo da ocorrência de um fenômeno linguístico, em que se fundem duas vogais idênticas, em função da tendência natural de simplificar a fala. Para se entender a ocorrência da crase, é preciso lembrar algumas regras simples, como classes de palavras, concordância nominal e regência verbal.

Nas primeiras lições de gramática, sobre classes de palavras, ensina-se que o artigo serve para acompanhar o substantivo. Ensina-se, ainda, que alguns verbos, os transitivos indiretos, precisam do auxílio de certas preposições que lhes completem o sentido. Descobre-se que algumas classes são mais importantes que as outras, pois não saem do dicionário para compor uma frase sem as suas "damas de companhia", cuja ausência, ou inadequação, comprometem o sentido do que se pretende escrever.

Uma regra básica, a da concordância nominal, determina que um substantivo feminino, no singular, deverá estar acompanhado de um artigo também feminino (concordância de gênero), e também no singular (concordância de número). Outra regra se refere à regência verbal. Alguns verbos, sozinhos, não fazem sentido e precisam de alguma preposição para lhes reger. Para entender melhor como ocorre a crase, vejamos o caso do verbo ir. Quem vai, vai a algum lugar. Vou (verbo ir) está regido pela preposição $a$ e praia (substantivo) está acompanhada do artigo $a$. Não se pode dispensar a preposição, nem o artigo, sob pena de se prejudicar o sentido da frase. Há outros verbos que são regidos por essa preposição. Uma consulta ao dicionário, caso não se disponha de uma gramática, pode ajudar.

Tente alguém dizer "Vou a a praia", pronunciando os dois "a", sem parecer gago. Se fosse um problema de matemática, ao invés de $a a$, bastaria escrever $2 a$. "Vou $2 a$ praia" também ficaria estranho, escrito ou pronunciado. A solução, então, seria fundir essas duas vogais numa só, para facilitar a pronúncia e a escrita. Para que os leitores saibam que duas vogais idênticas foram fundidas, e que são duas letrinhas que representam duas palavras inteiras e muito importantes para o entendimento do texto, melhor seria afixar uma placa sobre ela, com os dizeres "Atenção: aqui há uma preposição e um artigo". Estranho? Sim, muito estranho. É preferível usar o acento grave, indicativo da ocorrência de crase. Essa é a função daquele "risquinho".

Em razão disso, não se deve perguntar "aqui tem crase?", “devo usar a crase?”. Crase não é um acento, não existe crase, nem se usa crase. Crase ocorre. Crase acontece. A pergunta correta seria "O verbo que estou usando é regido pela preposição a?" e "A próxima palavra é ou começa pela letra a?" Se forem indispensáveis, ocorrerá sua natural fusão, que deverá ser indicada.

Há também expressões que contêm a preposição $a$ : referir-se a; com relação a; quanto a; se deve a; devido a. Nesses casos, o hábito da leitura e a prática da escrita vão ajudar a consolidar o aprendizado. Quanto à Botânica, refere-se à biologia relativa às plantas e muitos de seus registros se devem à dedicação de Linnaeus.

\section{A pontuação serve para separar ideias}

Certa vez, um mestrando me solicitou que revisasse sua dissertação, deixando claro que haveria divergências quanto ao uso da vírgula "porque vírgula é algo muito pessoal". De acordo com ele, vírgula serve "para marcar a respiração, e cada um respira do seu jeito". Como professor, tentei entender a lógica de seu raciocínio. Lembrei-me das primeiras professoras de leitura, que me aconselhavam a fazer uma pequena pausa nas vírgulas e uma pausa maior nos pontos finais, demorando-me mais nas mudanças de parágrafos. Uma inspiração curta, uma mais profunda e duas inspirações, respectivamente. Elas apenas se esqueceram de explicar que a pontuação serve para separar ideias, ou diversos itens dentro das ideias e que, se eu fizesse a pausa fora das vírgulas e pontos, poderia prejudicar o sentido da frase.

Parágrafos muito curtos - se um conjunto de ideias for suficientemente exposto em poucas frases, um assunto ou abordagem diferente exigirá um novo parágrafo. Atente-se, porém, que as ideias não deverão estar soltas, numa profusão de parágrafos curtos, sem coesão entre eles. Quando relacionar outros autores, seria interessante agrupar num parágrafo os que corroboram suas conclusões e, em outro, os que chegaram a conclusões divergentes da sua.

Parágrafos muito longos - se muitas frases forem necessárias para completar o raciocínio, o parágrafo será um pouco mais longo. Nesse caso, seria interessante verificar se não há informações duplicadas ou em excesso. Concisão é qualidade imprescindível ao texto científico.

\section{Considerações finais}

Para um constante aperfeiçoamento, seria interessante ter o apoio de uma gramática e um dicionário, que muito 
auxiliarão nas dúvidas naturais para todo escritor. Afinal, tais regras foram aprendidas quando da nossa adolescência e muitas outras preocupações se sobrepuseram a elas, nessa caminhada em busca do conhecimento. Afinal, tais regras foram aprendidas quando da nossa adolescência. Houve muitas mudanças de ordem ortográfica e gramatical na nossa língua. Difícil lembrar todas as regras e assimilar todas essas mudanças.. 